\title{
A Selected Bibliography of Shakespeare and Literary Onomastics*
}

\section{Elizabeth M. Rajec, Compiler}

Altick R.D., 1946. 'Conveyers' and Fortune's Buckets in Richard II. Modern Language Notes 61, 179-80.

Apperson, G.L. 1899. Some Shakespearean names. The Gentleman's Magazine 287, 27883.

Ardolino, F.R. 1982. 'In Saint Iagoes Parke': Iago as Catholic Machiavel in Dekker's The Whore of Babylon. Names 30, 1-4.

Ashley, L.R.N., and M.J.F. Hanifin. 1979. Onomasticon of Roman anthroponyms: Explication and application (Part II). Names 27, 1-45. See also Names 24 (1978), No. 4. Notes on names in the Roman plays.

Babcock, C.M. 1951. An analogue for the name Othello. Notes and Queries 196, 515.

Barner, S. 1957. Coleridge on puns: A note to his Shakespeare criticism. Journal of English and Germanic Philology 56, 602-9.

Bergdal, E., ed. 1929. Hamlet's name. Scandinavian Studies and Notes 10, 159-75.

Berry, R. 1978. The Shakespearean metaphor: Studies in language and form. Totowa, NJ: Rowman and Littlefield.

Bloom, A.D. 1960. Cosmopolitan man and the political community: An interpretation of Othello. American Political Science Review 54, 130-57. See interpretation of Desdemona's name.

Bluestone, M. 1953. An anti-Jewish pun in A Midsummer Night's Dream, III.i.97. Notes and Queries 198, 325-29.

Bolger, S.G. 1971. A logical note on 'Barbary.' Shakespeare Quarterly 22, 79-80.

Bowers, R.H. 1953. Polonius: Another postscript. Shakespeare Quarterly 4, 362-64.

Brockbank, J.P. 1958. History and histrionics in Cymbeline. Shakespeare Survey 11, 42-49. Derivation of character names.

Brown, J. 1956. Eight types of puns. Publications of the Modern Language Association 71, 14-26.

Brown, K. 1974. Polonius and Fortinbras (and Hamlet?) English Studies 55, 218-38.

Browne, C.E. 1873. On Shakespeare's pastoral name. Notes and Queries 12, 509-10.

* This bibliography was compiled independently of the one by Richard Coates. 
Brückner, A. 1914. Zum Namen Polonius. Archiv für das Studium der neueren Sprachen und Literaturen 132, 404-5.

Burelback, F.W. 1985. Name-play and internationalism in Shakespearean tragedy. Literary Onomastics Studies 12, 137-51.

Burns, W. 1946. The character of Marcius Coriolanus. Poet Lore 52, 31-48.

Calderwood, J.L. 1978. Hamlet: The name of action. Modern Language Quarterly 39, 33162.

Carter, A.H. 1961. The meaning of characters' names in Shakespeare. Mississippi Quarterly $15,33-39$.

Champion, L.S. 1968. Shakespeare's Nell. Names 16, 357-61.

Charosky, G.S. 1959. Macbeth: Classical and medieval drama. Lenguas Vivas 3, 21-28. Greek and Roman names in Macbeth.

Clark C. 1931. Shakespeare and the supernatural. London: Williams \& Norgate. See also later editions.

Conway, R.S. 1921. The classical elements in Shakespeare's Tempest. In New Studies of a Great Inheritance; Being Lectures in the Modern Worth of Some Ancient Writers. London: Murray. Greek mythology and classical onomastics. See also later editions.

Cook, E. 1984. Shakespeare's Emilia and Milton's "The Parameter of Research." English Language Notes 23, 8-19.

Crookes, D.Z. 1978. Note on the names and instruments of the musicians in Romeo and Juliet. Music Review 39, 1-3.

Cunningham, H. 1907-1933. Introduction to The Comedy of Errors. The Arden Edition of the Works of William Shakespeare. London: Methuen. See xi-xlv, particularly for interpretation of the name Antiphilus.

Dash, I.G. 1976. Bohemia's 'Sea Coast' and the babe who was 'lost forever.' Literary Onomastics Studies 3, 102-9.

Davis, N. 1975. Falstolf or Falstaff. English Literary Renaissance 5, 308-12.

Dibelius, W. 1912. Zur Stoffgeschichte des Titus Andronikus. Jahrbuch der deutschen Shakespeare-Gesellschaft 48, 1-12.

Erler, E. 1913. Die Namengebung bei Shakespeare. Heidelberg: Winter. Extensive study of Shakespeare's onomastics.

Everett, B. 1982. Spanish Othello: The making of Shakespeare's Moor. Shakespeare Survey 35, 101-2.

Fay, E.W. 1903. Further notes on the Mostellaria of Plautus. American Journal of Philology 24, 245-77. On tell-tale names in The Taming of the Shrew, The Tempest, and Merry Wives of Windsor.

Fleissner, R.F. 1976. Addendum: Chasing a ghost. Names 24, 75-76. On the name Othello.

French, G.R. 1869. Shakespeareana Genealogia. Part I, \& Part II. London: Macmillan. Identification of the characters in Shakespeare's plays, with notes on characters in the tragedies. 
Fuller, T. 1662. William Shakespeare. In The History of the Worthies of England. London: Printed by J. G. W. L. and W. G. See 483-84 on warlike names. See also later editions.

Godshalk, W.I. 1979. Pun in Shakespeare's sonnet i, line 4. English Language Notes 16, 200-2.

Gray, A. Feb. 17, 1927. The Comedy of Errors. The Times Literary Supplement, 108.

Griffin, W.J. 1936. Names in The Winter's Tale. The Times Literary Supplement (June 6), 480.

Guilfoyle, C. 1981. King Hamlet's two successors. Comparative Drama 15, 120-38.

Hales, J.W. 1884. Shakespeare's Greek names. In Notes and Essays on Shakespeare. London: Bell. See Ch. IV, 105-19. (Reprinted from the Cornhill Magazine (1876), 208-16.

1874. Shakespeare's pastoral names. The Academy 5, 37.

Halliwell-Phillipps, J.O. 1879. Memoranda on the 'Midsummer Night's Dream,' A.D. 1879 and A.D. 1855. Brighton: Fleet and Bishop. On names taken from Chaucer and Plutarch.

Hanifin, J.J.F. See Ashley, L.R.N.

Hart, H.C. 1903-1934. Introduction to The Tragedy of Othello. The Arden Edition of the Works of William Shakespeare. London: Methuen. See ix-xliv. For interpretation of Desdemona's name, see xxxi.

Hastings, W.T. 1939. Shakespeare's part in Pericles. Shakespeare Association Bulletin 14, 67-85.

Heinrich, P. 1904. Die Namen der Hamlettragödie. Leipzig: Faberland. On names in the tragedy Hamlet.

Herbert, T.W. 1977. Oberon's mazed world. Baton Rouge: Louisiana State University Press. On personal names in The Midsummer Night's Dream.

1949. Shakespeare's word-play on 'tombe.' Modern Language Notes 64, 235-41.

Herrick, M.T. 1950. Comic theory in the sixteenth century. Illinois Studies in Language and Literature 34, 1-248. On tag names.

Highet, G. 1957. What's in a name? In Talents and Geniuses. New York: Oxford. Refers to many names.

Horn, W. 1940. Zu Shakespeares Wortspielen. Archiv für das Studium der neueren Sprachen und Literaturen 178, 119-21. On puns.

Humphreys, A.R. 1981. Much Ado about Nothing. The Arden Edition of the Works of William Shakespeare. London: Methuen. See 87-88 on the names Verges and Dogberry.

Irvine, T.U. 1919. How to pronounce the names in Shakespeare. New York: Hinds. Also available in other editions and in reprint (Detroit: Gale, 1974).

1944. A pronouncing dictionary of Shakespearean proper names. New York: Barnes. See also later edition and above edition. 
Jerrold, W. 1905. A descriptive index to Shakespeare's characters in Shakespeare's words. London: Routledge. See also other edtion. Also available in reprint (Detroit: Gale, 1975).

Johnson, M. 1984. What's in a name: Astrology and onomastics in 'Romeo and Juliet.' Ph.D. diss., Princeton University.

Jones, W.M. 1960. Shakespeare's source for the name Laertes. Shakespeare Newsletter 10, 9.

Jorgensen, P. 1954. Much Ado about Nothing. Shakespeare Quarterly 5, 287-95. 1950. My name is Pistol call'd. Shakespeare Quarterly 1, 73-75.

Keller, W. 1935. Die Entstehung des 'Sommernachtstraums.' Anglia 59, 376-84.

Kerrigan, J. 1982. Shakespeare at work: The Katharine-Rosaline tangle in Love's Labour's Lost. Review of English Studies, N.S. 33, 129-36.

King, A.H. 1937. Notes on Coriolanus. English Studies 19, 13-20. On the name Martius versus Marcius.

1942. Some notes on ambiguity in Henry IV, Part 1. Studia Neophilologica 14, 161-83. On puns.

Kisbye, T. 1979. A thousand years of English influence in Danish masculine nomenclature. Nomina 3, 61-77. On names.

Kohl, N. 1970. Die Shakespeare-kritik zum Wortspiel. Deutsche Vierteljahrsschrift für Literaturwissenschaft und Geistesgeschichte 44, 530-45. Puns and wordplay.

Kökeritz, H. 1947. Five Shakespeare notes. Review of English Studies, 23, 310-20. On puns.

1950. Thief and stealer: A study of Shakespeare's punning technique. English and Germanic Studies 3, 57-60.

1946. Touchstone in Arden As You Like It II.iv.16. Modern Language Quarterly 7, 61-63. On puns.

Kulshreshtha, R.S. 1967. Shakespeare's feeling for words. The Literary Criterion 7 (summer), 6-19.

Kupper, H.J. 1977. A local habitation and a name. Deutsche Shakespeare Gesellschaft (West), Jahrbuch, 51-69. On Midsummer Night's Dream.

Kytzler, B. 1967. Classical names in Shakespeare's Coriolanus. Archiv für das Studium der neueren Sprachen und Literaturen 204, 133-37.

Lamb, M.E. 1985. The nature of topicality in Love's Labour's Lost. Shakespeare Survey 38, 49-59.

Lecercle-Sweet, A. 1984. Bases pulsionnelles de la phonation et sémantique du texte tragique. Sigma 8, 201-10. Names in King Lear.

Le Comte, E. 1984. Shakespeare's Emilia and Milton's The Parameters of Research. Milton Quarterly 18 (October), 81-84.

Lee, V. 1975. Puck's 'tailor': a mimic pun? Shakespeare Quarterly 26 (Winter), 55-57. On Midsummer Night's Dream. 
Lewis, C. 1985. A fustian riddle?: Anagrammatic names in Twelfth Night. English Language Notes 22 (June), 32-37.

Louthan, D. 1950. The 'tome-tomb' pun in renaissance England. Philological Quarterly 30, 375-80.

Macey, S.L. 1978. A turning picture in Shakespeare's Othello? Notes and Queries 25, 14546.

McIntosh, A. 1963. As You Like It: a grammatical clue to character. A Review of English Literature, 4 (April), 68-81. See also A. McIntosh and M.A.K. Halliday, Patterns of Language (Bloomington: Indiana University Press, 1966), 70-82.

MacIssac, W.J. 1978. A commodity of good names in the Henry IV plays. Shakespeare Quarterly 29, 417-19.

MacLean, H. 1977. Bassanio's name and nature. Names 25 (June), 55-62.

McNeal, T.H. 1953. The names Hero and Don John in Much Ado. Notes and Queries 198, 382.

Mahood, M.M. 1951. The fatal Cleopatra: Shakespeare and the pun. Essays in Criticism 1, 193-207.

1957. Shakespeare's Word Play. London: Methuen. See also later editions.

Main, W.W. 1951. Shakespeare's 'fear no more the heat o' th' sun' (Cym IV.ii). Explicator 9, 36.

Maury, L. 1924. Hamlet, Héros Méditerraneéen. Revue Bleue 62, 134-36.

Maxwell, J.C. 1949. Rope-tricks. Notes and Queries 194, 556.

May, R. 1972. Who's who in Shakespeare. London: Elm Tree. See also other editions.

Meier, K. 1907. Uber Shakespeares Sturm. Die neueren Sprachen 16, 193-210, 271-79, and 321-36. On Caliban's name.

Miller, J.H. 1977. Ariachne's broken woof. Georgia Review 31, 44-60. On Troilus and Cressida.

Milward, P. 1968. What's in a name? A study in Shakespeare nomenclature. English Literature and Language 5, 1-11.

'Modernizing' Shakespeare's names. 1986. The Shakespeare Newsletter, 36/1 (Spring), 9 and 17. A brief note on 'spelling' of names by students.

Montgomerie, W. 1943. English Seneca. Life and Letters Today 36, 25-28. On the name Claudius in Hamlet.

Muir, K. 1950. The uncomic pun. Cambridge Journal 3, 472-85.

Musgrove, S. 1956. The nomenclature of King Lear. Review of English Studies, N.S. 7, 294-98.

Mustanoja, Y.F. 1955. Middle English 'with an $O$ and an I,' with a note on two Shakespearean 'O-I' puns. Neuphilologische Mitteilungen 56, 161-73.

Nares, R. 1822. A Glossary: or, Collection of Words, Phrases, Names ... London: Triphook. See later editions with slightly varying titles. See also reprint (Detroit: Gale, 1966). 
Nathan, N. 1970. 'Abram' not 'Abraham' in The Merchant of Venice. Notes and Queries $17,127-28$.

1959. The Goodwins: an appropriate name. Names 7, 191-92.

1986. Osric's name and Oswald's. Names 34, 234-35.

Nearing, Homer, Jr. 1947. A three-way pun in Richard II. Modern Language Notes 62, 3133.

Niva, W.N. 1959. Significant character names in English drama to 1609. Ph.D. diss., University of Pennsylvania.

Nixon, P.. 1927. Martial and the modern epigram (Our debt to Greece and Rome, No. 18). New York: Longman. On martial names.

Parrott, T.M. 1948. Pericles: The play and the novel. Shakespeare Association Bulletin 23, 105-13. Claims that names are consistent with Greek and Latin onomastic practices.

Perry, T.A. 1954. Proteus, wry transformed traveller. Shakespeare Quarterly 5, 33-40.

Phillipps, J.O. Halliwell. See Halliwell-Phillipps, J.O.

Platt, I.H. 1904. Polonius and Corambis. New Shakespeareana 3, 83-84.

Pollard, A.F. 1937. A Shakespearean pun? The Times Literary Supplement (April 3), 256.

Pyle, F. 1952. Hostilius: Timon of Athens III.ii.70. Notes and Queries 197, 48-49.

Ragussis, M. 1986. Acts of naming: The family plot in fiction, 229-60. New York: Oxford University Press.

Rea, J.A. 1986. Iago. Names 34, 97-98.

1984. The linguistic confrontation of 'Macbeth' and 'Macduff.' Names 32, 102-3.

Reaske, C.R. 1974. A Shakespearean backdrop for Dryden's MacFlecknoe? Shakespeare Quarterly 25, 358.

Richer, Jean. 1974. Le rituel et les noms dans 'Le Songe d'une nuit de la minété. In Etudes et recherches de littérature générale et comparée. Paris: Belles Lettres.

Rydén, M. 1978. Shakespearean plant names: Identifications and interpretations. Stockholm: Almqvest.

Schäfer, J. 1970. The orthography of proper names in modern-spelling of Shakespeare. Studies in Bibliography 23, 1-19.

Schrickx, W. 1956. Shakespeare's early contemporaries: The background of the HarveyNashe polemic and 'Love's Labour's Lost.' Antwerp: Nederlandsche Boekhandell. See also later edition on mythological names.

Scragg, L. 1985. The Shakespearian 'Antonio.' English Language Notes 23 (September), 819.

Sélten, B. 1968-1969. Early East Anglican nicknames: Shakespeare Names. Lund: CWK Gleerup.

Shaaber, M.A. 1950. Shylock's name. Notes and Queries 195, 236.

Shakespear's [sic] Greek names. 1876. Cornhill Magazine 33, 208-16.

Siler, H.D. 1945. A French pun in Love's Labour's Lost. Modern Language Notes 60, 12425.

Sillars, S. 1978. Phobe and Phoebus: Bottom's verbal slip. Notes and Queries 25, 125-26. 
Sipahigil, T. 1976. Sagitary/Sagittar. Shakespeare Quarterly 27, 200-1. On the name in Othello.

Skeat, W.W. 1875. Shakespeare's Plutarch .... London: Macmillan. On names possibly drawn from Plutarch.

Smith, W.H. 1887. Shakespeare and Shake-speare and Pallas Athene. Notes and Queries 4, 66.

Spevack, M. 1955. The Dramatic Function of Shakespeare's Puns. Ph.D. diss., Harvard University.

Stotsenburg, J.H. 1904. An Impartial Study of the Shakespeare Title. Louisville: Morton. See 192-203.

Strachan, L.R.M. 1934. The spelling 'Anthony.' Notes and Queries 167, 85-86.

Sweet, A. Lecercle-. See Lecercle-Sweet, A.

Tesch, A. 1930. Das Nachleben der Antike in Shakespeares Draman. Wiener Blütter für die Freunde der Antike 7, 38.

1929. Zum namen Desdemona. Germanisch-Romanische Monatsschrift 17, 38788.

Tolman, A.H. 1904. The views about 'Hamlet' and other essays. Boston: Houghton. See reprint (New York: AMS, 1973).

Vaganay, H. 1935. Quatre noms propres dans la littérature: Délie, Philothée, Ophélie, Pasithée. Revue de littérature comparée 15, 279-88.

Vining, E.P. 1891. Shakespeare's Latin derivatives. Shakespeariana 8, 104-7. See particularly for names in Hamlet.

Vouk, V. 1960. Shakespearean names in Serbo-Croatian translation. Studia Romanica et Anglica Zagrebiensia. 191-98.

Weidhorn, M. 1969. The relation of title and name to identity in Shakespearean tragedy. Studies in English Literature 9, 303-19.

1969. The rose and its name: On denomination in Othello, Romeo and Juliet and Julius Ceasar. Texas Studies in Literature and Languages 11, 671-86.

Weingarten, S. 1966. The name of King in Richard II. College English 27, 536-41.

Wells, S. 1976. A note on Demetrius's vile name. Cahiers Elisabéthains 10, 67-68.

Williams, F.B., Jr. 1954. Renaissance names in 'Masquerade.' Publications of the Modern Language Association 69, 314-23.

Williams, G.W. 1976. The text of 2 Henry IV. Shakespeare Studies 9, 173-82. See also 1979, Shakespeare Quarterly 30, 82-84.

Willson, R.F. 1969. A note on symbolic names in Macbeth and Anthony and Cleopatra. College English Association Critic (May), 7.

1977. Sh- and Shakespeare in Dryden's MacFlecknoe. Names 25, 155-57.

Winser, L. 1975. His Madness the King. American Notes and Queries 14, 5-7. On the implication that 'Majesty' is a pun on 'Ma(d)jesty' in Hamlet.

Woodson, W.C. 1978. Iago's name in Holinshed and the lost English source of Othello. Notes and Queries 25, 146-47. 
Yates, F.A. 1947. Queen Elizabeth as Astraea. Journal of the Warburg and Courtauld Institutes 10, 27-82. On Astraea's name in Timon of Athens.

Young, A.R. 1979. Prospero's table: The name of Shakespeare's Duke of Milan. Shakespeare Quarterly 30, 408-10.

Zimmermann, H. 1975. Die personifikation im drama Shakespeares. Heidelberg: Quelle \& Meyer.

The City College of the City University of New York

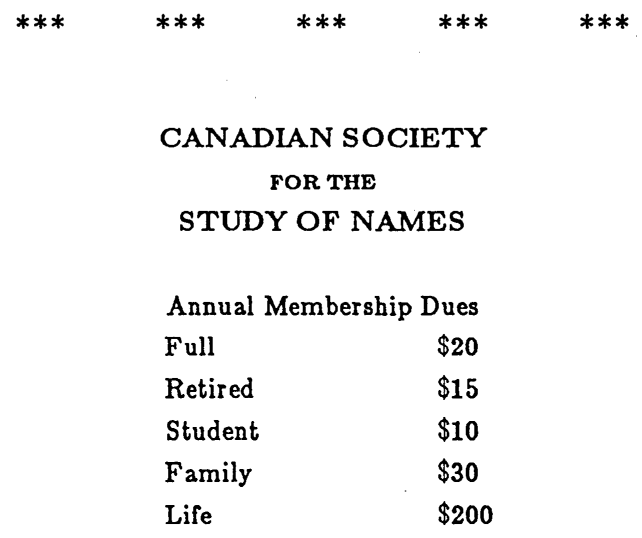

Introductory offer for 1987: new annual membership $\$ 10$

(Dues are the same whether paid in US or Canadian funds.)

Members receive two numbers of Onomastica Canadiana each year and occasional issues of The Name Gleaner.

Members of CSSN may receive financial assistance to attend its annual meeting. Proposals for papers, membership dues, and all inquiries should be sent to:

\author{
Helen Kerfoot \\ Secretary-Treasurer \\ Canadian Society for the Study of Names \\ P.O. Box 6626, Station J \\ Ottawa, Ontario K2A $3 \mathrm{Y} 7$
}

